\title{
A NEW DETERMINATION OF THE ATOMIC WEIGHT OF OSMIUM ${ }^{1}$
}

\author{
By Raleigh Gilchrist
}

ABSTRACT

A method for the preparation of pure osmium is described. The value of the atomic weight of osmium is calculated from the average percentage of osmium found in carefully prepared samples of ammonium chloroosmate and of ammonium bromoosmate. The value obtained from the ratio $\left(\mathrm{NH}_{4}\right)_{2} \mathrm{OsCl}_{6}$ : Os is 191.53 , and from the ratio $\left(\mathrm{NH}_{4}\right)_{2} \mathrm{OsBr}_{6}: \mathrm{Os}$ is 191.57 , based upon the values for nitrogen, hydrogen, chlorine, and bromine given in the International Table of Atomic Weights for 1932. The weighted average value is 191.55.

The densities of ammonium chloroosmate and of ammonium bromoosmate at $25^{\circ} \mathrm{C}$. were found to be $2.93 \mathrm{~g} / \mathrm{cm}^{3}$ and $4.09 \mathrm{~g} / \mathrm{cm}^{3}$, respectively.

\section{CONTENTS}

I. Introduction

II. Preparation of pure osmium

1. Extraction of osmium from crude material

2. Purification of the osmium 280

III. Preparation of reagents

IV. Preparation of ammonium chloroosmate

V. Preparation of ammonium bromoosmate

VI. Determination of the osmium content of ammonium chloroosmate and of ammonium bromoosmate.

1. Apparatus _............ 285

2. Balances, weights, and weighing 285

3. Analysis

4. Densities of the substances weighed 288

5. Results

VII. Discussion of results

VIII. Acknowledgments

\section{INTRODUCTION}

Osmium was first identified as a new element by Tennant, ${ }^{2}$ who discovered it in the portion of crude platinum which is not attacked by aqua regia. Osmium occurs as a constituent of a natural alloy with iridium known as osmiridium or iridosmine. The name osmium,

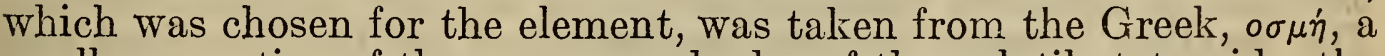
smell, suggestive of the pronounced odor of the volatile tetroxide, the formation of which is the most outstanding property of the metal.

The earliest attempt to determine the atomic weight of osmium was made by Berzelius, ${ }^{3}$ who analyzed potassium chloroosmate, $\mathrm{K}_{2} \mathrm{OsCl}_{6}$, and obtained the value 198.94 from the ratio Os:2 $\mathrm{KCl}$.

Seubert, ${ }^{4} 60$ years later, undertook to make careful analyses of potassium chloroosmate and of ammonium chloroosmate, $\left(\mathrm{NH}_{4}\right)_{2} \mathrm{OsCl}_{6}$,

1 Submitted as partial fulfillment of the requirements for the degree of doctor of philosophy, The Johns Hopkins University, June 1922.

2 Smithson Tennant, Phil. Trans., vol. 94, p. 411, 1804.

3 J. J. Berzelius, Ann. Physik (Pogg.), vol. 13, p. 530, 1828.

' K. Seubert, Ber., vol. 21, p. 1839, 1888; Ann., vol. 261, p. 258, 1891. 
and it is upon his experiments that the value of the atomic weight was based which has appeared in the International Table of Atomic Weights for many years. Seubert used the ratios $\left(\mathrm{NH}_{4}\right)_{2}$ $\mathrm{OsCl}_{6}: \mathrm{Os} ; 6 \mathrm{AgCl}:\left(\mathrm{NH}_{4}\right)_{2} \mathrm{OsCl}_{6} ; \mathrm{K}_{2} \mathrm{OsCl}_{6}: \mathrm{Os}_{2} ; \mathrm{K}_{2} \mathrm{OsCl}_{6}: 2 \mathrm{KCl}$; and $4 \mathrm{AgCl}: \mathrm{K}_{2} \mathrm{OsCl}_{6}$. The values obtained for the atomic weight range from 190.27 to 192.22 when recalculated on the basis of the International Table of Atomic Weights for 1932. The value calculated from Seubert's experiments on the osmium content of ammonium chloroosmate is 191.24 .

In the last 41 years only one published account of new work on the atoic mweight of osmium has appeared, that of Seybold ${ }^{5}$, describing the determination of the osmium content of ammonium chloroosmate. The value calculated from a set of three experiments is 191.09 , while that from five other experiments is 189.33 .

\section{PREPARATION OF PURE OSMIUM}

\section{EXTRACTION OF OSMIUM FROM CRUDE MATERIAL}

The osmium used in the experiments reported in this paper was obtained from two sources. That used in ammonium chloroosmate, Series VI, was obtained from one of the platinum companies, while that used in the other experiments was recovered from the osmiridium residues from grain platinum.

The crude material was fused with sodium hydroxide and sodium nitrate in a gold dish. The aqueous extract of this melt was acidified with nitric acid and distilled. The osmium tetroxide thus obtained was absorbed in a 10 per cent solution of sodium hydroxide and again distilled as just described. The remaining platinum metals, ${ }^{6}$ under these conditions, do not appear in the distillate. The osmium was recovered by electrolysis from the alkaline solution, into which the tetroxide had been distilled the second time, using platinum electrodes. The osmium separated at the cathode as a black, loosely adherent deposit which, according to Moraht and Wischin, ${ }^{7}$ is the dioxide. The precipitated material was washed as free from alkali as possible, dried, and ignited to metal in hydrogen. Spectrographic examination of the metal thus obtained showed that it was free from the other platinum metals, but that it did contain traces of sodium and of iron.

\section{PURIFICATION OF THE OSMIUM}

In considering possible reactions feasible for the preparation of pure osmium, it appeared highly desirable to employ volatile reagents. The reaction between osmium tetroxide and hydrochloric acid had been studied by Milbauer, ${ }^{8}$ who observed that osmium tetroxide was decomposed by concentrated hydrochloric acid at room temperature with the evolution of chlorine. Ruff and Mugdan, ${ }^{9}$ however, using acid of specific gravity 1.124, stated that the reaction reported by Milbauer did not take place. A few years later, Renyy made a careful study of the reaction at room temperature and concluded that the reaction depends considerably upon the concentration of the

6 F. Seybold, Inaugural-Dissertation, 1912, Friederich-Alexanders Universität, Erlangen.

6 R. Gilchrist, B. S. Jour. Research, vol. 6, p. 421, 1931.

7 H. Moraht and C. Wischin, Z. anorg. Chem., vol. 3, p. 153, 1893.

8 J. Milbauer, J. prakt. Chem. (2), vol. 96, p. 187, 1917.

9 O. Ruff and S. Mugdan, J. prakt. Chem. (2), vol. 98, p. 143, 1918.

10 H. Remy, J. prakt. Chem. (2), vol. 101, p. 341, 1921. 
hydrochloric acid. He found that with hydrochloric acid of specific gravity greater than 1.160 the osmium tetroxide was decomposed with appreciable velocity, with the evolution of chlorine. He further found that the osnium was converted to the quadrivalent state and not to the bivalent, as asserted by Milbauer. Krauss and Wilken ${ }^{11}$ later substantiated Remy's conclusion regarding the quadrivalent state.

In a recent study by Crowell ${ }^{12}$ of the reaction between octavalent osmium and hydrobromic acid at $100^{\circ} \mathrm{C}$., it was found that the products formed are quadrivalent osmium and bromine and that an equilibrium is reached. It was also found that in concentrated hydrobromic acid (about 8 normal) the reaction goes to practical completion in the direction of the formation of quadrivalent osmium and bromine, while in dilute acid solutions (about 0.1 normal) the reaction goes to completion in the reverse direction.

In 1920, previous to the appearance of Remy's paper, the author observed that reaction occurred when a mixture of osmium tetroxide and 20 per cent ${ }^{13}$ hydrochloric acid (constant-boiling acid) was heated to incipient boiling and that the presence of a small quantity of ethyl alcohol assisted in the decomposition of the tetroxide. After about three hours the odor of osmium tetroxide disappeared and the solution, which had gradually turned deep brown in color, became reddish yellow and transparent. This solution, when evaporated to sirupy consistency, appeared to suffer no decomposition. Ammonium chloride, added to an acid solution of the sirupy residue, precipitated the brick red ammonium chloroosmate, $\left(\mathrm{NH}_{4}\right)_{2} \mathrm{OsCl}_{6}$. Ignition of the precipitate in hydrogen produced metallic osmium in the spongy form. It was further observed that the reaction between osmium tetroxide and 20 per cent hydrobromic acid proceeded with greater ease and rapidity than that between osmium tetroxide and hydrochloric acid. Considerable bromine was produced. Enough alcohol was added just to destroy the bromine vapor in the refluxing flask. The resulting solution was deep brown in color and likewise appeared to suffer no decomposition on evaporation to a sirup. Ammonium bromide precipitated the deep brownish black animonium bromoosmate, $\left(\mathrm{NH}_{4}\right)_{2} \mathrm{OsBr}_{0}$, from an acid solution of the sirupy residue.

The osmium metal obtained by reduction of the product of electrolysis previously described was converted in turn into osnium tetroxide, chloroosmic acid, ammonium chloroosmate, and osmium sponge as will be described in detail in connection with the preparation of the compounds for analysis. This cycle of operations was repeated twice, using purified reagents. The resulting metal was found on spectrographic examination to be free from impurities and was used in the final preparation of the compound ammonium chloroosmate.

\section{PREPARATION OF REAGENTS}

Hydrochloric acid.-Chemically pure hydrochloric acid of commerce (specific gravity 1.18) was diluted with an equal volume of distilled water and distilled three times from a ground-olass stoppered Pyrex flask whose side arm extended a considerable distance into the tube of a condenser. In each case the first and last fractions were discarded.

${ }_{13}$ Here and elsewhere in this paper the percentage of acid is percentage by weight. 
Bromine and hydrobromic acid.-Chemically pure bromine of commerce was purified by the procedure described by Baxter and Grover. ${ }^{14}$ Hydrobromic acid was prepared by reducing bromine with hydrogen in the presence of a catalyst consisting of pumice impregnated with platinum. The hydrogen was produced by electrolysis in a cell described later. The first portion of the hydrobromic acid was discarded. The remainder was dissolved in water and distilled once. Ammonium chloride.-Ammonium hydroxide, which had been freshly prepared by saturating distilled water with ammonia from a cylinder of liquid ammonia, was gently heated and the ammonia conducted into the purified hydrochloric acid until the acid was neutralized. A slight excess of acid was then added to the solution of ammonium chloride.

Ammonium bromide.-Ammonium bromide was prepared in the same manner as the ammonium chloride.

Alcohol.-Ethyl alcohol of commerce (95 per cent) was allowed to remain in contact with lime for several days, after which it was distilled three times. The first and last portions from each distillation were discarded.

Water.-In the preliminary work, the water used was purified by distilling from an alkaline permanganate solution and then from a



FIGURE 1.-Apparatus for the preparation of osmium tetroxide

dilute sulphuric acid solution, using a Pyrex distilling flask and a block-tin condenser. The preparation reported as ammonium chloroosmate, Series VI, was likewise made with water thus prepared. In the other three preparations reported, the water used was that which was regularly supplied to the chemical laboratories at the Bureau of Standards from a still by a pipe of block tin. This water gave no test for halides and had a specific conductance of about $1 \times 10^{-6}$ reciprocal ohm at room temperature.

\section{PREPARATION OF AMMONIUM CHLOROOSMATE}

Preparaition VI.-Osmium, which had been prepared from the material obtained from one of the platinum companies as described in Section II, was converted to osmium tetroxide by heating it in a current of oxygen. Figure 1 shows the apparatus used. A bottle, $A$, containing water, served to indicate the flow of oxygen. A tube, $B$, of combustion glass, having a diameter of about $2.5 \mathrm{~cm}$, was bent at an angle and the end inserted into a Pyrex flask which contained purified constant-boiling hydrochloric acid. The flask and contents were cooled by immersion in crushed ice in order to prevent too great a loss of osmium tetroxide. The combustion tube was heated by a 
12-inch Hoskins electric furnace of the split type. When heated to a temperature of from $220^{\circ}$ to $230^{\circ} \mathrm{C}$. the osmium, contained in porcelain boats, absorbed oxygen rapidly and reached a glowing temperature. This rapid absorption of oxygen was repeatedly observed and probably indicated the formation of osmium dioxide. As the temperature was raised the oxidized osmium was converted to tetroxide which condensed to a pale yellowish mass, as well as to white crystals, in the cooler portion of the combustion tube. Gentle warming of the tube with a flame loosened the solidified tetroxide, while a jet of hot hydrochloric acid solution from a wash bottle completely removed all tetroxide from the tube as it was lifted from the flask.

The contents of the flask, consisting of osmium tetroxide and hydrochloric acid, were quickly transferred ${ }^{15}$ to a refluxing flask to which a water-cooled condenser was attached by a ground joint. A $U$ tube containing a solution of sodium hydroxide was attached to the top of the condenser to prevent the escape of any tetroxide vapor. A quantity of purified constant-boiling hydrochloric acid, four times the amount necessary to form chloroosmic acid, $\mathrm{H}_{2} \mathrm{OsCl}_{6}$, was added to the refluxing flask. From 3 to $5 \mathrm{ml}$ of purified alcohol was added, and the mixture gently heated for one hour. During this time the color changed from faint yellow to deep brown. As heating was continued, droplets of osmium tetroxide gradually ceased to appear on the walls of the flask and the solution finally became reddish yellow in color and transparent. The total time of heating was about three hours, during the last hour of which the solution was kept at incipient boiling. The solution of chloroosmic acid which had been formed was evaporated to a sirup on the steam bath. On cooling, the sirupy solution solidified to a mass of crystals. These crystals were dissolved in purified constant-boiling hydrochloric acid and the resulting solution diluted with water so as to form a solution containing 4 per cent of osmium and 7 per cent of hydrochloric acid. This solution was filtered first through hardened paper, in a Gooch crucible, and then through blue ribbon paper (S. and S. No. 589).

A 15 per cent solution of purified ammonium chloride, in slight excess, was added slowly to the constantly stirred solution of chloroosmic acid at room temperature. The precipitate of ammonium chloroosmate, brick red in color, was caught on a hardened filter in a Gooch crucible and washed with a 15 per cent solution of purified ammonium chloride until the wash waters were colorless. The ammonium chloroosmate thus prepared was recrystallized by making a saturated solution of the compound in a solution containing 7 per cent of hydrochloric acid at about $90^{\circ} \mathrm{C}$. The hot saturated solution was quickly filtered through a hardened filter and cooled to about $5^{\circ} \mathrm{C}$. while being stirred. The supernatant liquid was decanted and the crystals of ammonium chloroosmate stirred with several portions of 7 per cent hydrochloric acid. The crystals were then caught on a hardened filter, in a Gooch crucible, drained by suction, washed with a dilute solution of hydrochloric acid, and finally washed with purified alcohol. The crystals were drained free from alcohol, spread on a watch glass and dried in a partially evacuated desiccator containing phosphorus pentoxide. The dried salt was thoroughly mixed by grinding in an agate mortar and kept in a desiccator until used.

${ }^{15}$ It is, perhaps, needless to mention that an operation of this kind should be conducted with care and that it is preferable to wear a mask to prevent the vapor of the tetroxide from attacking the eyes, nose, and throat of the operator. 
Preparation VII.-Osmium, which had been prepared from osmiridium residues from grain platinum as described in Section II, was converted into chloroosmic acid. A solution of the chloroosmic acid was made which contained 1.5 per cent of osmium and 1.7 per cent of hydrochloric acid. This solution was slowly added, at room temperature, to a dilute solution (approximately 2 per cent) of purified ammonium chloride which was constantly stirred, according to one of the procedures used by Archibald ${ }^{16}$ in the preparation of ammonium chloroplatinate. The precipitate of ammonium chloroosmate was not recrystallized, but was washed, dried, and mixed as described under Preparation VI.

\section{PREPARATION OF AMMONIUM BROMOOSMATE}

Preparation VI.-The ammonium bromoosmate was made from the osmium sponge ${ }^{17}$ resulting from the analyses of ammonium chloroosmate. The source of the osmium was the osmiridium residues from grain platinum. This osmium was first converted into tetroxide as previously described, then into bromoosmic acid, ammonium bromoosmate, and again into metal using purified reagents. The metal prepared by this cycle of reactions was again converted into bromoosmic acid. The resulting solution of bromoosmic acid was evaporated to a sirup on the steam bath, then evaporated twice more with 20 per cent hydrobromic acid. The crystalline mass was dissolved in 20 per cent hydrobromic acid and diluted with water to form a solution containing 1.5 per cent of osmium in 7 per cent of hydrobromic acid. This solution was filtered twice through filter paper (S. and S. No. 589, blue ribbon). A 2 per cent solution of purified ammonium bromide, in slight excess, was added slowly to the constantly stirred solution of bromoosmic acid at room temperature. The precipitate of ammonium bromoosmate, deep brownish black in color, was caught on a hardened filter and washed with a 15 per cent solution of ammonium bromide until the wash waters were colorless. The compound thus prepared was recrystallized by making a saturated solution of it in a solution containing 15 per cent of hydrobromic acid at about $90^{\circ} \mathrm{C}$. The hot saturated solution was quickly filtered through a hardened filter and cooled to about $10^{\circ} \mathrm{C}$. while being stirred. The supernatant liquid was decanted and the crystals washed with 7 per cent hydrobromic acid. The crystals were then caught on a hardened filter, in a Gooch crucible, drained by suction, washed with a dilute solution of hydrobromic acid and finally washed with purified alcohol. The crystals were drained free from alcohol and dried over phosphorus pentoxide. The dried salt was then thoroughly mixed by grinding it in an agate mortar and kept in a desiccator over phosphorus pentoxide until used.

Preparation VII.-This preparation was made from another portion of the same sponge as Preparation VI and in the same manner except that the compound was recrystallized from 10 per cent hydrobromic acid.

16 E. H. Archibald, Proc. Roy. Soc., Edinburgh, vol. 29, p. 721, 1908-9.

17 A portion of this sponge was used by Meggers to measure the spectral lines of osmium. W. F. Meggers, Arc Spectra of the Platinum Metals, B. S. Sci. Papers No. 499, Jan. 23, 1925. 


\section{DETERMINATION OF THE OSMIUM CONTENT OF AMMONIUM CHLOROOSMATE AND OF AMMONIUM BROMOOSMATE}

\section{APPARATUS}

The apparatus used in determining the osmium content of the preparations just described is shown in Figure 2. It consisted of an electrolytic cell for the generation of hydrogen; two series of scrubbing and drying towers; and a reaction tube, electrically heated.

The electrolytic cell was equipped with platinum electrodes and contained a dilute solution of potassium hydroxide. An electrically heated porcelain combustion tube, containing asbestos and quartz both impregnated with palladium, was inserted in the line to convert to water any oxygen which might have diffused into the hydrogen chamber of the cell. The series of five towers for the purification of the hydrogen contained silver sulphate, sulphuric acid which had previously been heated to heavy fumes, soda-lime, sulphuric acid, and phosphorus pentoxide which had been sublimed into the tower. Glass beads were used in all liquid towers, and several layers of beads were used in the soda-lime tower.

The nitrogen was the commercial gas produced by the fractionation of liquid air. The method used to remove the small amount of oxygen present was based upon the experiments of Badger, ${ }^{18}$ who found that a solution of ammonium hydroxide (1 volume of ammonium hydroxide, specific gravity 0.90 , diluted with 1 volume of water), when saturated with ammonium chloride and kept in contact with metallic copper, absorbed oxygen quantitatively. In order to insure the complete removal of oxygen a tube 6 feet in length, containing copper and the ammoniacal solution, was placed between the wash bottle and the first tower, which also contained the same solution. The second tower in this series contained 50 per cent sulphuric acid to absorb ammonia. The last five towers were similar to the set of towers described for the purification of hydrogen.

The reaction tube of combustion glass was fitted to the purification train by a carefully ground joint. Two $U$ tubes, containing glass beads and sulphuric acid, sealed the exit of the reaction tube. The Hoskins electric furnace which was previously mentioned was used to heat the reaction tube. At a few places in the apparatus where it was not possible to make sealed-glass connections, the ends of the rigid tubes were held flush by rubber tubing. A heavy coating of De Khotinsky cement was then applied so that the rubber tubing was completely covered. In order to make certain that no oxygen reached the reaction chamber, either from the hydrogen or from the nitrogen, these gases were alternately passed through the heated tube in the presence of spongy metallic osmium. A tube containing phosphorous pentoxide, attached directly to the reaction tube, indicated no formation of water.

\section{BALANCES, WEIGHTS, AND WEIGHING}

The experiments on ammonium chloroosmate, Series VI, were made at The Johns Hopkins University. The balance used in these experiments was a new analytical balance known as Ainsworth QA.

The experiments on ammonium chloroosmate, Series VII, and on ammonium bromoosmate, Series VI and VII, were made at the 


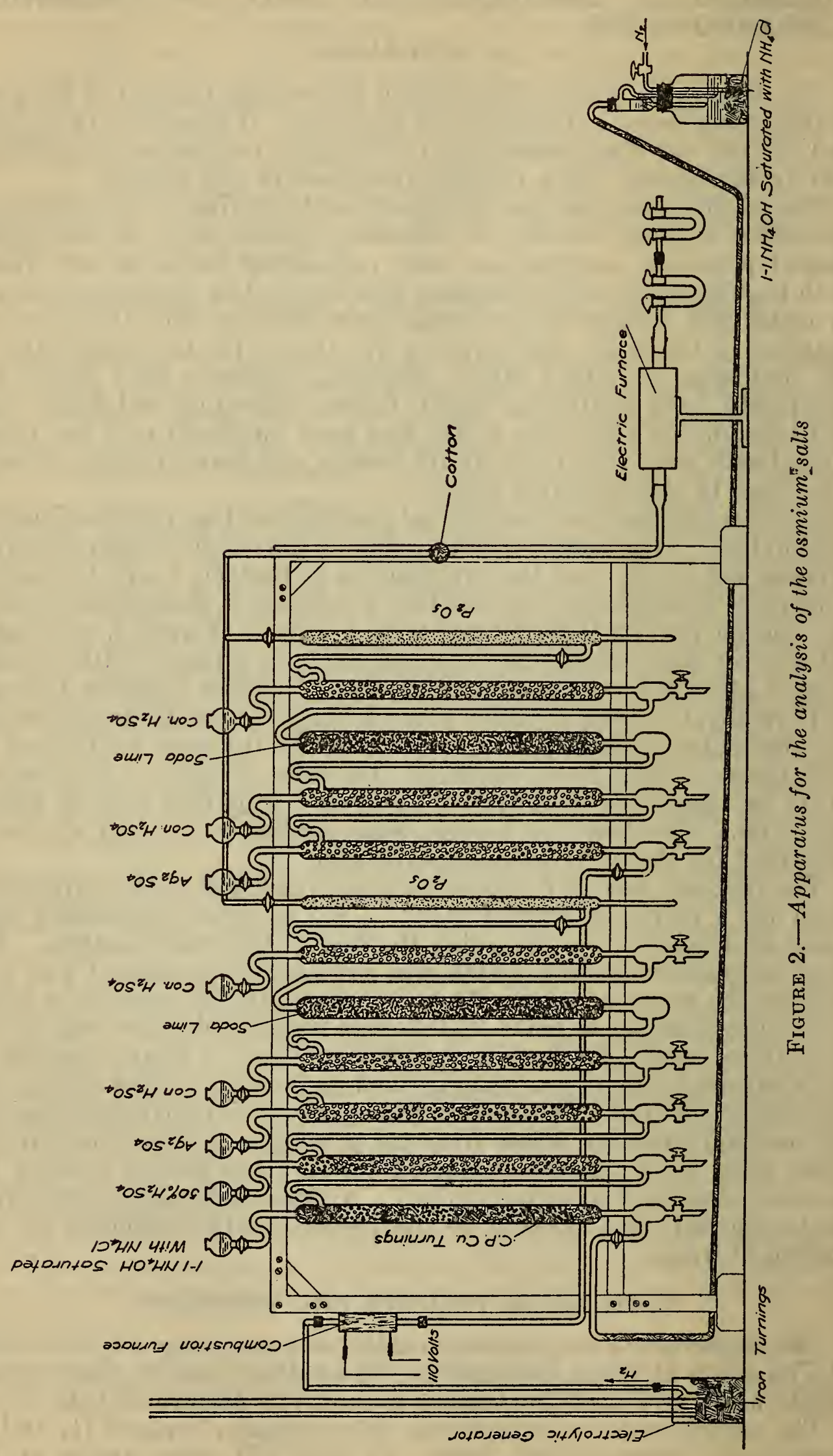


Bureau of Standards. The balance used in these experiments was made by Ruprecht, ${ }^{19}$ of Vienna, and was designed to carry a maximum load of $1 \mathrm{~kg}$ on each pan. This balance was inclosed in a case of blackened copper which served as a radiation screen. The weights used were carefully calibrated by the Bureau of Standards just previous to use.

Two glass weighing tubes of nearly the same size and weight, each fitted with a ground-glass stopper, were used. The boats were of porcelain. Weighing was done by the method of substitution, the vessels being allowed to remain in the balance case for three hours previous to weighing.

\section{ANALYSIS}

One is led to infer that Seubert ${ }^{20}$ dried his compounds only over phosphorous pentoxide in a desiccator. Seybold,,$^{21}$ cognizant of Seubert's procedure, in addition heated his preparations at $105^{\circ} \mathrm{C}$., most likely in air so far as one is able to tell from his description.

Archibald, ${ }^{22}$ in the analysis of ammonium chloroplatinate and of ammonium bromoplatinate, found that the purest samples which he was able to prepare began to decompose slightly at a temperature above $185^{\circ} \mathrm{C}$. and that all hydrochloric acid and hydrobromic acid seemed to be driven off below $150^{\circ} \mathrm{C}$.

With ammonium chloroosmate and ammonium bromoosmate it was found that slight decomposition occurred, in an atmosphere of dry purified nitrogen, if the temperature was above $170^{\circ} \mathrm{C}$. At temperatures up to $150^{\circ} \mathrm{C}$. no evidence of decomposition was observed. In experiment No. 1, ammonium chloroosmate, Series VII, the sample was heated for three 2-hour periods at $156^{\circ}$ to $160^{\circ} \mathrm{C}$. There was no change in weight during the second and third heating periods. When the temperature was raised to $166^{\circ}$ to $170^{\circ}$, however, a faint white sublimate was formed and the sample continually decreased in weight. A solution of the sublimate in water gave a precipitate with silver nitrate. The weight recorded for the sample was that obtained at $156^{\circ}$ to $160^{\circ} \mathrm{C}$. These same temperature limits were also observed with ammonium bromoosmate.

Experiments previously made on other preparations, in which the drying was done at about $175^{\circ} \mathrm{C}$., gave values for the atomic weight about 0.5 of a unit higher than those reported here. These values must be in error for the reason stated above and were rejected.

In the experiments reported here, the samples taken for analysis were dried to constant weight in a current of dry purified nitrogen. The samples in Series VI, ammonium chloroosmate, were dried from 3 to 5 hours at $140^{\circ}$ to $145^{\circ} \mathrm{C}$. Those in Series VII, ammonium chloroosmate, with the exception of No. 1 discussed above, were dried from 4 to 7 hours at $145^{\circ}$ to $150^{\circ} \mathrm{C}$. The samples in Series VI, ammonium bromoosmate, were dried from 10 to 14 hours at $150^{\circ}$, while in Series VII the first sample was dried for 14 hours at $145^{\circ}$ and the second for 12 hours at $150^{\circ} \mathrm{C}$. During the heating of the sample in experiment No. 2, ammonium chloroosmate, Series VII, a tube containing phosphorous pentoxide showed no increase in weight after the first heating period of 3 hours, although the sample was heated during two additional periods of 2 hours each.

i2 See footnote 16, p. 284. 
The decomposition of the compounds was accomplished as follows:

The porcelain boat with its contents was placed in the reaction tube. The tube was swept with dry purified nitrogen for one hour. The nitrogen was displaced by pure dry hydrogen for one and one-hals hours, at the end of which time the temperature of the tube was gradually raised. When the decomposition appeared to be complete, the temperature was increased to $700^{\circ}$ to $725^{\circ} \mathrm{C}$. and maintained at this point for two hours. While at this temperature the hydrogen was displaced by dry purified nitrogen for one hour. The boat, now containing metallic osmium, was allowed to cool to room temperature in nitrogen, the furnace having been removed. The boat was placed in the glass-stoppered weighing tube and allowed to remain in the balance case for three hours before being weighed.

This procedure for the very gradual decomposition of the osmium compounds had been found, in previous experiments, to give a metal sponge which remained constant in weight upon reignition in hydrogen. No mechanical loss of material could be detected during the decomposition. With the exception of four instances where the metal sponges were returned to the cleaned reaction tube for an additional heating period of three hours in hydrogen at $700^{\circ}$ to $725^{\circ} \mathrm{C}$., the weights recorded in this paper were those obtained after the above treatment. The metal sponges in experiments Nos. 1 and 2, ammonium chloroosmate, Series VII, lost 0.00091 and $0.00051 \mathrm{~g}$, respectively, on reheating in hydrogen. In these two cases the time of the first reduction had been cut somewhat short owing to the late hour of the night, so that all traces of volatile matter had apparently not been completely eliminated. The weight of the metal sponge in experiment No. 2, ammonium bromoosmate, Series VI, remained unchanged on reheating, while that in experiment No. 2, ammonium bromoosmate, Series VII, lost $0.00006 \mathrm{~g}$. The weights recorded for these four sponges were those after the second heating period.

It had been repeatedly observed that metallic osmium, which had been ignited and cooled in hydrogen, was rapidly attacked by the air with the formation of osmium tetroxide. When the reaction tube was opened, the surface of the metal sponge usually glowed and a distinct odor of the tetroxide was noticeable. When the atmosphere of hydrogen was displaced as described in the experiments reported here, no odor of osmium tetroxide was detected either on opening the reaction tube or several days later when the boat was finally removed from the weighing tube. The limiting quantity of osmium tetroxide which von Wartenberg ${ }^{23}$ could detect by the sense of smell was $2 \times 10^{-5} \mathrm{mg} / \mathrm{cm}$.

\section{DENSITIES OF THE SUBSTANCES WEIGHED}

In order to reduce the weights obtained to vacuum, the densities of the two osmium compounds and of the resulting osmium sponge were determined at $25^{\circ} \mathrm{C}$. by displacement of toluene which had been dried and redistilled.

Two determinations of the density of ammonium chloroosmate were made, using 6.2303 and $8.7552 \mathrm{~g}$ of the compound. The values found were 2.941 and $2.908 \mathrm{~g} / \mathrm{cm}^{3}$. The average value was $2.93 \mathrm{~g} / \mathrm{cm}^{3}$.

Two determinations of the density of ammonium bromoosmate were made, using 10.2161 and $10.5552 \mathrm{~g}$ of the compound. The

${ }^{23}$ H. von Wartenberg, Ann., vol, 44,0, p. 97, 1924. 
values found were 4.102 and $4.084 \mathrm{~g} / \mathrm{cm}^{3}$. The average value was $4.09 \mathrm{~g} / \mathrm{cm}^{3}$.

One determination of the density of the osmium sponge was made, using $6.7478 \mathrm{~g}$. The value found was $19.13 \mathrm{~g} / \mathrm{cm}^{3}$.

A correction of $+0.00026,+0.00014$, and $-0.00009 \mathrm{~g}$ was applied to each gram of ammonium chloroosmate, ammonium bromoosmate, and osmium sponge, respectively.

\section{RESULTS}

The results of the determinations are given in Tables 1 and 2 .

TABLE 1.-Results of the analysis of ammonium chloroosmate

\begin{tabular}{|c|c|c|c|c|c|}
\hline 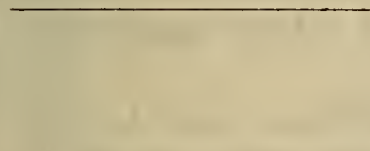 & $\begin{array}{c}\text { Experi- } \\
\text { ment } \\
\text { No. }\end{array}$ & $\begin{array}{l}\text { Weight of } \\
\left(\mathrm{NH}_{4}\right)_{2} \mathrm{OSCl}_{6} \\
\text { in vacuum }\end{array}$ & $\begin{array}{l}\text { Weight } \\
\text { of os- } \\
\text { mium in } \\
\text { vacuum }\end{array}$ & $\begin{array}{l}\text { Percent- } \\
\text { age of } \\
\text { osmium }\end{array}$ & $\begin{array}{l}\text { A tomic } \\
\text { weight }\end{array}$ \\
\hline$\left(\mathrm{NH}_{4}\right)_{2} \mathrm{OSCl}_{6}$, Series VI. & $\begin{array}{l}1 \\
2 \\
3\end{array}$ & $\begin{array}{l}g \\
\text { 3. } 81131 \\
3.46016 \\
1.11090\end{array}$ & $\begin{array}{l}g \\
\text { I. } 65758 \\
\text { J. } 50505 \\
.48320\end{array}$ & $\begin{array}{l}\text { 43. } 491 \\
43.496 \\
43.497\end{array}$ & 1 \\
\hline$\left(\mathrm{NH}_{4}\right)_{2} \mathrm{OsCl}_{6}$, Series VII.. & $\begin{array}{l}1 \\
2 \\
3 \\
4\end{array}$ & $\begin{array}{l}7.80602 \\
7.21775 \\
7.04888 \\
7.54170\end{array}$ & $\begin{array}{l} \\
\text { 3. } 39547 \\
\text { 3. } 13949 \\
\text { 3. } 06644 \\
\text { 3. } 27946\end{array}$ & $\begin{array}{l}43.495 \\
43.499 \\
43.496 \\
43.502 \\
43.484\end{array}$ & is \\
\hline 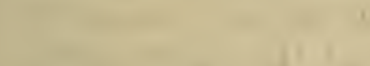 & & & & 43. 495 & 191. 53 \\
\hline
\end{tabular}

TABLE 2.-Results of the analysis of ammonium bromoosmate

\begin{tabular}{|c|c|c|c|c|c|}
\hline+ & $\begin{array}{c}\text { Experi- } \\
\text { ment } \\
\text { No. }\end{array}$ & $\begin{array}{l}\text { Weight of } \\
\left(\mathrm{N}^{N} \mathrm{H}_{4}\right)_{2} \mathrm{OsBr}_{6} \\
\text { in vacuum }\end{array}$ & $\begin{array}{l}\text { Weight } \\
\text { of os- } \\
\text { mium in } \\
\text { vacuum }\end{array}$ & $\begin{array}{l}\text { Percent- } \\
\text { age of } \\
\text { osmium }\end{array}$ & $\begin{array}{l}\text { A tomic } \\
\text { weight }\end{array}$ \\
\hline \multirow[t]{2}{*}{$\left(\mathrm{NH}_{4}\right)_{2} \mathrm{OsBr}_{6}$, Series VI... } & \multirow[t]{2}{*}{$\begin{array}{l}1 \\
2 \\
3\end{array}$} & \multirow[t]{2}{*}{$\begin{array}{l}g \\
5.85596 \\
5.59980 \\
3.31834\end{array}$} & \multirow[t]{2}{*}{$\begin{array}{l}\stackrel{g}{8} \\
\text { 1. } 58647 \\
\text { 1. } 51471 \\
1.06117\end{array}$} & $\begin{array}{l}27.091 \\
27.093 \\
27.082\end{array}$ & \\
\hline & & & & 27.089 & 191.55 \\
\hline \multirow[t]{2}{*}{$\left(\mathrm{NH}_{4}\right)_{2} \mathrm{OSBr}$, Series VII_.. } & \multirow[t]{2}{*}{$\begin{array}{l}1 \\
2\end{array}$} & \multirow[t]{2}{*}{$\begin{array}{l}\text { 4. } 98331 \\
\text { 4. } 53546\end{array}$} & \multirow[t]{2}{*}{$\begin{array}{l}\text { 1. } 35016 \\
1.22899\end{array}$} & $\begin{array}{l}27.093 \\
27.097\end{array}$ & $(x) 1$ \\
\hline & & & & 27.095 & 191.61 \\
\hline
\end{tabular}

The average percentage of osmium in ammonium chloroosmate, combining the results of the two series, was 43.495 . The average percentage of osmium in ammonium bromoosmate, again combining the results of the two series, was 27.091 . Using the values

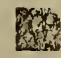
N 14.008
H 1.0078
thi
Cl 35.457
$\mathrm{Br} 79.916$

the ratio $\left(\mathrm{NH}_{4}\right)_{2} \mathrm{OsCl}_{6}$ : Os yields the value 191.53 for the atomic weight while the ratio $\left(\mathrm{NH}_{4}\right)_{2} \mathrm{OsBr}_{6}$ : Os yields 191.57 . The weighted average value is 191.55 .

\section{DISCUSSION OF RESULTS}

It is recognized that complex compounds of the platinum metals, of the type considered here, sometimes undergo a change of composition through hydrolysis. Such is known to be the case with 
potassium chloroplatinate when formed under the conditions which obtain in the usual analytical separation of potassium from sodium. The change of composition comes about through the partial replacement of halogen by the hydroxyl group. The effect of such a change would be to raise the percentage of osmium and hence the apparent atomic weight. Except by accidental compensation the effect would be to produce a divergence in the values of the atomic weight calculated from similar ratios on analogous compounds. The probability that such change occurred in the compounds examined here is held to be highly unlikely, since the compounds were precipitated and recrystallized from solutions containing varying quantities of acid, and the value of the atomic weight as calculated from one compound agrees so closely with that calculated from the other analogous compound.

No impurities were detected in the metallic osmium used to prepare the compounds for analysis. The compounds were made by using only volatile reagents.

In the present work the samples of ammonium chloroosmate and of ammonium bromoosmate were dried to constant weight at temperatures of $140^{\circ}$ to $150^{\circ} \mathrm{C}$. A loss of weight was always observed in the first drying period when the salts, which had merely been desiccated over phosphorus pentoxide, were heated at $140^{\circ}$ to $150^{\circ} \mathrm{C}$. No evidence of decomposition was detected below $170^{\circ} \mathrm{C}$. The probability that the compounds so treated still retained significant amounts of volatile impurities is held to be unlikely because of the close agreement of the values of the atomic weight calculated from the two ratios. The net effect of such impurities would be, of course, to lower the percentage of osmium and hence the apparent atomic weight, but a divergence in the ratios would result unless the relative amounts of the impurities in the two compounds happened to be such as to compensate for it.

The decomposition of the compounds in hydrogen was accomplished so gradually that the possibility of mechanical loss appears improbable.

The formation of only volatile products upon decomposition and the constancy of weight of the resulting metallic osmium, when heated in hydrogen at an elevated temperature, make it highly improbable that any impurity contaminated the final metal. The removal of hydrogen at an elevated temperature by nitrogen undoubtedly prevented the attack of the metal sponge by atmospheric oxygen during the time necessary to make the weighings.

The identical agreement of the average determinations of the osmium content of the two preparations of ammonium chloroosmate, when different quantities of the substances were taken and when different balances were used, makes it improbable that significant errors were introduced in weighing.

\section{ACKNOWLEDGMENTS}

The author wishes to express his gratitude for the help and encouragement received from Prof. J. C. W. Frazer, of The Johns Hopkins University, under whose supervision the research was conducted, and for the many valuable suggestions received from Edward Wichers.

WAshington, June 8, 1932. 